\title{
Learners' Strategies for Transliterating English Loanwords into Katakana
}

\author{
Esther Lovely \\ The University of Queensland
}

\begin{abstract}
Post-World War II, the Japanese language has experienced massive influxes of foreign words and expressions into its lexicon, known as "loanwords" or borrowings. These lexical items are commonly written in Japanese using katakana symbols. Transliterating these words into katakana accurately is a primary source of difficulty for foreign learners of Japanese. Previous studies in the field of learners' transliteration of foreign loanwords have focused mainly on error analysis and no formal study has investigated the basis for learners' methods of transliteration.
\end{abstract}

Using a combination of interviews and think-aloud procedures, 21 students at the University of Queensland, who were studying 1st year Japanese courses, were surveyed. The students transliterated a list of selected loanwords and expressions into katakana, while responding to inquiries about their transliterations and verbalising their mental processes. These interviews were then analysed for evidence of strategies. The students also completed a short survey on their learning background and exposure to the Japanese language outside the classroom. Strategies were subsequently identified and the answers to the surveys were analysed for evidence of correlations between students with a higher level of accuracy in transliteration and their strategies and extra-curricular exposure.

\section{Keywords}

Katakana, loanwords, transliteration, strategies, JFL

\section{Introduction}

Loanwords have been a part of the Japanese language since Chinese characters were adopted as Japan's first writing system around 800 A. D. ${ }^{1}$ In addition to kango, or words of Chinese origin, loanwords from other foreign languages, known as gairaigo, have been adopted into the Japanese lexicon. In 1987, Neustupný estimated that loanwords made up about $6 \%$ of the Japanese lexicon. In recent years analyses of newspaper texts have shown this figure to have risen to $10 \%$, with $80 \%$ of loanwords originating from 
the English language. ${ }^{2}$ This phenomenon has triggered government action, such as the bunka shingikai kokugo bunka-kai (Ministry of Cultural Affairs National Language Subdivision) paper on the transcription of foreign loanwords, public surveys by the Ministry conducted from 2003 - 2006 designed to investigate the comprehensibility of foreign loanwords to the Japanese public, and the formation of a gairaigo iinkai (Foreign Loanword Committee) whose mission is to replace loanwords of low comprehensibility with original native Japanese words. ${ }^{3}$ Researchers have also conducted newspaper analyses in order to determine the rate of increase of loanwords in circulation. ${ }^{4}$

In the teaching of Japanese as a foreign language (JFL), the current pedagogy of foreign loanwords relies on inductive learning as defined by DeKeyser, ${ }^{5}$ that is, individual examples of the correct form are presented to learners before the rules are explained. Hulstijn ${ }^{6}$ states that deductive and inductive learning are by definition both part of explicit instruction because rules are always given at some point. However, few textbooks introduce these rules, even ones designed at focusing on katakana. This is evidenced in katakana resource books such as "Learning katakana words from the news - 350 Words" ${ }^{7}$ which exposes learners to loanwords in the context of modified newspaper articles, but does not teach them about rules or strategies that may be helpful in approaching the transliteration of these words.

This is also because rules for transliteration do not exist in a single, comprehensive and consistent framework. It would be more accurate to say that there are systems of guidelines for transliteration compiled by government bodies and language researchers, ${ }^{8}$ which show variation in their presentation, including exceptional cases, occasional contradictions between rules and omissions of certain rules from different sources. Therefore learners currently seem unequipped to engage in deductive learning on the transliteration of foreign loanwords. As indicated by the studies mentioned below, japanisation and transliteration of loanwords continue to pose common problems for learners of JFL. It is also the author's anecdotal experience that JFL learners find loanwords problematic.

An important point is that loanwords have properties that make them useful lexical items for English native speakers learning Japanese. Loanwords that are cognates have similar or guessable meanings in English compared to their original

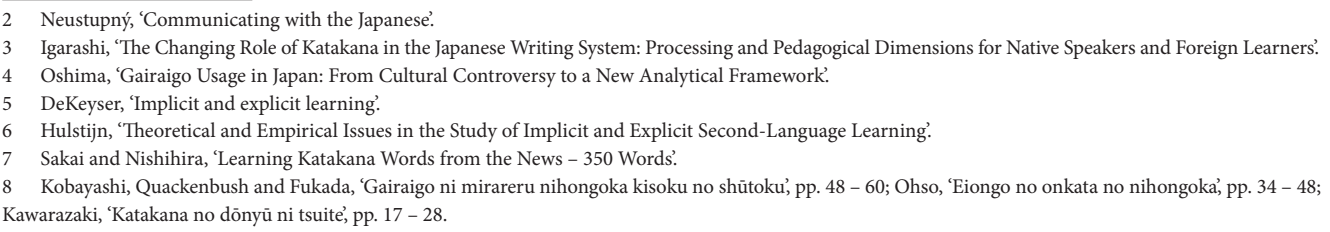


form and phonological realisation which makes them easy to remember. Japanising the pronunciation of English words when a Japanese word is unknown is a possible way of being understood by Japanese native speakers because there is also a remote chance that the word might happen to be a loan, or the word may be recognised by Japanese who have had exposure to formal English learning during primary and secondary education. ${ }^{9}$ Therefore, knowing how to correctly Japanise English words can facilitate JFL learners' communication skills.

Previous studies in the field by Kobayashi, Quackenbush and Fukada, ${ }^{10}$ Inagaki, ${ }^{11}$ and $\mathrm{Ohso}^{12}$ have used error analysis to identify stops, long vowel sounds and palatals as elements frequently transliterated inaccurately by learners of JFL. These studies have made anecdotal assumptions that learners are guided in their transliterations by either the English spelling of the loanword or by their own pronunciation. No other studies so far have attempted to investigate whether learners transliterate using other strategies.

In contrast to previous studies dealing with the transliteration of loanwords in katakana, methodologically the study reported here took a qualitative approach to investigating the strategies used by learners to transliterate loanwords into katakana. Here, learners of JFL participated in individual interviews in which they were asked questions about their reasons for deciding on a particular transliteration. Further, while transliterating any specific test words, JFL learners were asked to verbalise their mental processes in a method known as "think-aloud procedure". "Think-aloud" procedures have found application in previous second language acquisition studies, particularly those relating to studies of learners' reading comprehension. ${ }^{13}$ In addition, this study developed profiles of individual participants, having students complete a survey about their prior JFL learning experience and extra-curricular exposure to Japanese. Due to the small size of the participant group, qualitative elements were analysed in addition to quantitative in order to identify and evaluate the success of learners' strategies for transliteration.

This study aimed to identify and then to evaluate the strategies learners use to transliterate loanwords into katakana symbols. By combining think-aloud procedures with interviews, this study took a qualitative approach so far not attempted by researchers in this area. The results provided new insight into learners' thinking and decisionmaking processes with regards to the transliteration of loanwords and use of katakana symbols. Analysis of the participants' learner history and extra-curricular exposure

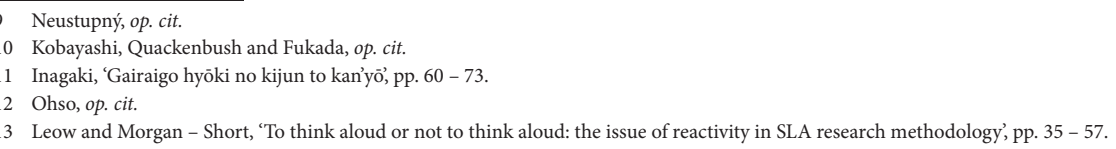


to Japanese language also provided evidence linking certain types of exposure with greater accuracy of transliteration, which could lead to the development of an improved teaching model or a new learning resource for loanwords, which are an integral part of the evolving Japanese lexicon.

\section{Research Methodology}

In this study, three instruments were used to collect data. These were a Learner History Questionnaire, a written test and an interview in which learners were encouraged to explain aloud their reasons for transliterating a word in a particular way.

\section{Participants}

All participants were first year students at the University of Queensland, who had completed at least one Japanese language course of 178 hours in Semester 1 2007, through the School of Languages and Comparative Cultural Studies. With the cooperation of Japanese language lecturers, I was able to email students information about the study, and recruit volunteers during lectures and Japanese language conversation groups. Over a period of approximately one month, twenty-one students volunteered to participate and were recruited and interviewed. Of the 21 participants, 10 were male, 11 were female, and three were aged 21 years and over, while the remaining 18 were 18 to 20 years old. Seventeen of the participants were native English speakers, while two were native Mandarin speakers, one was a Cantonese native speaker, and one identified as Swedish/English bilingual.

\section{Learner History Questionnaire}

Participants were given a Learner History Questionnaire which asked for information on a participant's age, gender, learning stream, prior formal learning experience of JFL, and any extra-curricular exposure to the Japanese language. The questionnaire was designed to provide a more detailed indication of the scope and nature of learners' exposure to formal and informal experiences of learning Japanese. Data on the extent and varieties of exposure was later correlated with learners' strategy use and accuracy of transliteration in order to investigate which types of and how much exposure produce higher accuracy of transliteration. 


\section{Test Sheet}

Participants were also asked to transliterate a selection of ten English words and expressions into katakana. Nine of these were the same as those used in Kobayashi, Fukada and Quackenbush's loanword transliteration study. ${ }^{14}$ Their study required learners to transliterate a list of 48 words, each one involving one or more japanisation rules as posited in the aforementioned study.

Participants transliterated the words into katakana. If they wished to change an answer, they were asked to circle the original response, and write the new answer beside it, in order to preserve all data. The words selected for use in my study were those in Table 1.

Table 1. English words and expressions used in this study

\begin{tabular}{|l|l|l|}
\hline English word & Japanese transliteration & Romanized representation \\
\hline Beige & ベージュ、゙ージ & bēju, bēji \\
\hline Bus terminal & バス・ターミナル & basu tāminaru \\
\hline Massage & マッサージ & massāji \\
\hline Yellow & イエロー & ierōo \\
\hline Question mark & クェスチョンマーク & kwesuchonmāku \\
\hline Mother & マザー & mazāa \\
\hline Tulip & チューリップ & chūrippu \\
\hline Cash card & キャッシュ・カード & kyasshu kādo \\
\hline Hammer & ハンマー & hanmāa \\
\hline Guitar & ギター & gitā \\
\hline
\end{tabular}

Preston and Yamagata's loanword transliteration study ${ }^{15}$ focused on learners' accuracy in transliterating English geminates ${ }^{16}$ into katakana, using $\%$, the small tsu symbol representing a phonological stop. This study was based on the earlier-established premise that using this symbol appropriately is an area of difficulty for learners. ${ }^{17}$

4 Kobayashi, Quackenbush and Fukada, op. cit., pp. 48 - 60.

15 Preston and Yamagata, 'Katakana representation of English loanwords: Moraconservation and variable learner strategies', pp. 359 - 379.

16 A 'doubled' or long consonant, according to The American Heritage Dictionary".

17 Kawarazaki, op. cit., pp. 17 - 28; Kobayashi, Quackenbush and Fukada, op. cit., pp. 48 - 60; Inagaki, op. cit., pp. 60 - 73. 
Lengthened vowel sounds were often transliterated incorrectly by learners, according to Kobayashi, Quackenbush and Fukada; ${ }^{18}$ Inagaki; ${ }^{19}$ Kawarazaki; ${ }^{20}$ and Ohso. ${ }^{21}$ Inagaki ${ }^{22}$ also identified palatals as problematic.

Based on these findings, I purposely selected words and expressions that contained these problematic elements. All ten words and expressions in my list include at least one long vowel sound, and three out of the ten include a stop (ツ) - "massage" "tulip" and "cash card". Four also include one or more palatals in Japanese - ベージュ、ベージ bēju, bèji “beige”, ク エスチョンマーク kwesuchonmāku "question mark", チューリップ chūrippu “tulip", and キ ヤッシュ・カード kyasshu kādo "cash card". I also investigated how students would attempt to transliterate sounds not naturally occurring in Japanese phonology, such as [ð], [ə] and [33], which are found in the items "mother", "hammer" and "bus terminal" respectively.

\section{Think-aloud procedures in Previous Research}

According to Gass and Selinker, ${ }^{23}$ the most common methodologies used in researching learning strategies are observations, verbal self-reports or online protocols (often called think-aloud protocols). However, they acknowledge that '... it is difficult, though perhaps not impossible, to observe mental behaviour of learners. ${ }^{24}$

The structure of a typical think-aloud interview is as follows:

1. Students are given a task to work on, which may be a reading comprehension text, a 'fill in the blank' passage or a taped text to listen to.

2. Students are asked to describe their thoughts before, during and after the task in real time.

3. The interviewer prompts the student with general questions or reminders (e.g. 'What are you thinking right now?').

4. The student is either allowed a moment to pause and think-aloud, or the task is marked for places in which they are to think-aloud.

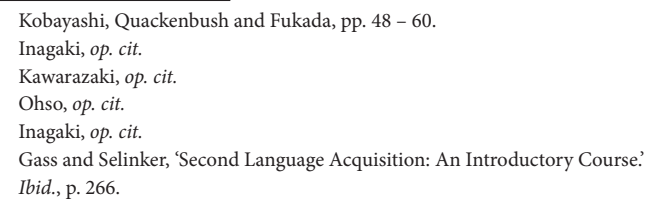


5. The interview is recorded and later transcribed word for word. ${ }^{25}$

Think-aloud procedures were first used to investigate the processes of learning and using a language in the 1970s by Hosenfeld, who identified the characteristics of more effective readers through think-aloud procedures conducted during reading tasks. ${ }^{26}$ Later studies conducted by O'Malley, Chamot and Küpper, ${ }^{27}$ and Chamot and Küpper, ${ }^{28}$ identified differences in strategies between more and less effective language learners. O'Malley and $\mathrm{Chamot}^{29}$ used think-aloud procedures (which they refer to as on-line processing studies) to identify Language Learning Strategies (LLS) that students used and to discover in greater detail what students meant when they said they used a specific strategy.

\section{Benefits of Think-Aloud Procedures}

The advantage of the think-aloud procedure is that it has the potential to capture the learner's thought processes while they are actually performing a task. Another benefit of using the procedure is its capacity to discover strategies which have become automatic to the extent that they are only registered momentarily in the short-term memory. ${ }^{30}$ Oxford and Crookall's paper ${ }^{31}$ about research conducted on language learning strategies mentions a number of specific studies which aimed to discover learners' strategies by either interviewing learners, listening to them think-aloud, or by combining the two procedures, as in this study.

\section{Limitations of Think-Aloud Procedures}

O'Malley and Chamot discuss two areas for concern regarding data collected by selfreport methods: the concurrence of a learner's verbal report with their actual thought processes and changes in these processes which could be effected by questions asked during the data collection. ${ }^{32}$ Cohen $^{33}$ refuted the former concern by noting that a concurrent introspective approach such as self-observation or self-revelation, rather than a retrospective approach, can gain a more accurate picture of the learner's

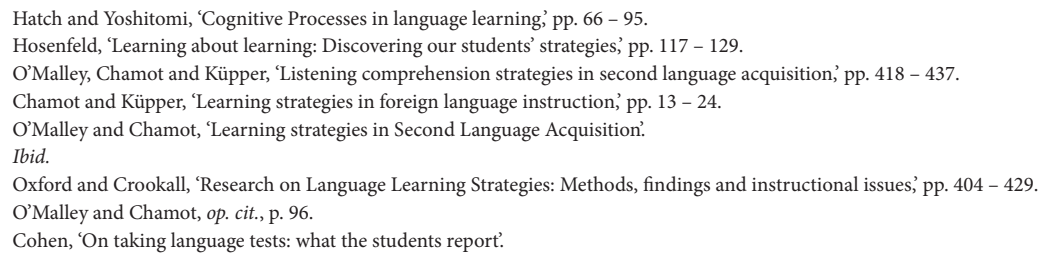


thought processes. The latter issue was addressed by Brown et al., ${ }^{34}$ who noted that although it may have a detrimental effect on the learning process, thinking aloud does not tend to alter the fundamental reasoning process. Indeed, as identified by Ericsson and Simon, ${ }^{35}$ the major internal change that occurs during the think-aloud process is that the thinking processes must slow down enough to allow thoughts to be verbalised.

In the process of conducting this study, I was confronted with each of the following limitations, and devised ways to manage them as much as possible. O'Malley and Chamot $^{36}$ found the limitation that learners, becoming sensitised to what the researcher is interested in, may invent strategies and reasons without any real foundation. This situation could arise also in an atmosphere where a participant feels pressured to provide a valid reason for every response. The degree of success achieved in a thinkaloud procedure relies at least partially on the strength of the rapport and the level of comfort which the researcher is able to attain with the student. The more comfortable a student is in an interview, the less reticent they will be about sharing thoughts and reasons which may seem to them unreasonable or invalid. For the purposes of a thinkaloud procedure, which is designed to capture a learner's raw and unadorned mental processes, an informal atmosphere is therefore the most conducive. It is also beneficial to inform the student, explicitly or otherwise, that there are no incorrect answers, and that all reasons have validity.

A limitation of the method from the perspective of researchers concerned with learning strategies is that with this method, learners typically have no opportunity of planning for learning and reflecting after task completion. ${ }^{37}$ However, by providing planning time before the task, and eliciting self-evaluation from the learners after the task, this limitation can be overcome. ${ }^{38}$

\section{Think-aloud procedure in this study}

For the purposes of this study, participants completed a short written test as described earlier and were encouraged to explain their reasons for transliterating a word in a particular way. Participants were questioned immediately after completing task items and again after the written portion of the study, so that the strategies which they had used were still fresh in their short-term memories. In order not to influence participants' responses, I refrained from initiating discussion or criticism of their responses during the interview.

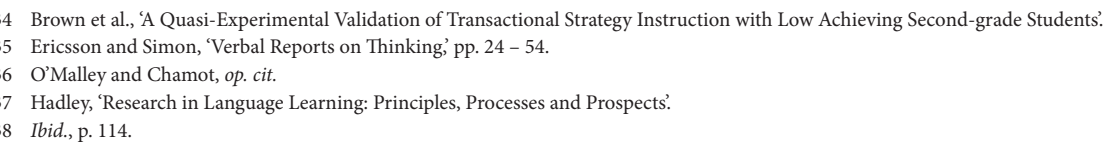


The primary task of the researcher is to create an interview atmosphere most conducive to accomplishing their objectives; in this case, a low pressure, relaxed ambience.

Each participant was interviewed individually, with interviews lasting up to fifteen minutes in length. There was no set time limit; each interview continued until the participants felt they had nothing further to contribute. The participants' main task was to write down their transliterations of the English words on the test sheet, while verbalising their reasons for transliterating a word in a certain way. As they did so, I verbally acknowledged their comments and encouraged them to voice their ideas. My principal role however, was to ask participants to justify their transliterations. Questions of this nature were asked while they were transliterating test words and after they had completed the test. The following are typical examples of the types of questions I asked participants:

'So why do you think you spelt “yellow” like this?' (to Participant 12)

'Why did you put a long sound here do you think?' (to Participant 17)

'Why do you think you put small "tsu"?' (to Participant 8)

Because it has been established in previous studies that stops, long vowel sounds and palatals are frequently transliterated inaccurately by JFL learners, I focused on asking questions about participants' transliterations of these elements, or other areas where a participant expressed uncertainty or difficulty while transliterating.

\section{Results}

Upon examination of the transcripts of the participants' interviews, five distinct strategies for transliteration became apparent, which were named and characterised as follows.

\section{Precedent (P)}

The precedent strategy was used when a participant transliterated according to their memory of a word or construction to which they previously had been exposed. Use of this strategy was expressed in explanations such as, 'I've seen it before' (Participant 14), 'I've seen it on another word somewhere, a similar construction to that one' (Participant 21), "'er" is always the longest one' (Participant 17), 'In many Japanese words they used to use "shon"' (Participant 12) etc. In particular, Participant 19's comment 'I notice they like to add little sounds at the end' (Participant 19), almost describes an established rule. 
Reasons under this category were usually coherent and required little interpretation to identify the inherent strategy.

\section{English Pronunciation (EP)}

This strategy was used when students transliterated a word with the goal of imitating their perception of the word's original pronunciation when spoken by English native speakers. Participants' explanations in this category encompassed those which included the word "English," for example, 'it sounded closer to the English sound' or in which they made reference to the "original" pronunciation of the word, or stated that it was 'how I'd say the word'. In some instances, participants stated that they were trying to achieve a certain sound which was present in the original pronunciation of the word; these explanations were also placed under the English Pronunciation strategy.

\section{English Spelling (ES)}

The English Spelling strategy refers to the situation where a participant was guided in their transliteration of a word by its original English written form. This strategy was commonly used when participants were confronted with a geminate (repeated consonant) in the words "massage," "yellow" and "hammer". Explanations which indicated use of this strategy were clearly and explicitly expressed compared to those indicating use of other strategies. For example reasons such as, 'because it's the double m' (Participant 4), or 'because there's i in the English word', (Participant 17), required little interpretation. As a consequence this strategy was more easily identified than the other strategies described here.

\section{No Rule (NR)}

This strategy, or lack thereof, encompasses instances where the participant could provide no explanation for their transliteration of a word. 'I don't know' and 'I'm not sure' were typical responses under this category. Statements which were considered to be incomplete or not indicative of any strategy also fell into this category. For example, in response to being questioned as to why she had used a vowel extending symbol in a particular position, Participant 20 replied 'to make it sound longer'. Although this comment was offered as an explanation, actually the participant did not provide any relevant information. 


\section{Inductive Rules (IR)}

The Inductive Rules strategy was the strategy most commonly used by the participants (fifteen out of the twenty-one used it as their dominant strategy). It refers to cases where the participant transliterated according to internal rules; rules of their own formulation which they a) invented by themselves, or b) have unconsciously internalised or derived from outside sources, a process encompassing inductive learning or c) remember explicitly or implicitly, that is, with or without conscious awareness. Inductive Rules discussed here are not to be confused with established rules posited by previous researchers and Japanese government bodies, as mentioned in the Introduction. The majority of JFL learners are unaware of and lack knowledge of these established rules. Therefore these learners can construct a system of Inductive Rules without having awareness or knowledge of rules which have been officially recognised.

Explanations which indicated the use of the Inductive Rules strategy were characterised by phrases such as 'it looks right', 'it seems right', 'I think it should be like this'; all expressions that implied that the participant was transliterating according to some internal standard or yardstick. Even if they were unable to verbalise the nature of the rule or its source, such justifications provide evidence of the existence of internal systems by which some learners transliterate.

\section{Analysis and Discussion}

After the five strategies were identified, the strategies which each participant used predominantly were determined to discover the range of strategies used by individuals and whether strategic preferences exist. This was achieved by individually assigning a strategy to each highlighted explanation then counting the numerical frequency with which each strategy was used, as a proportion of the total number of reasons given by the participant. Twelve of the twenty-one participants used two of the strategies with almost equally high frequency and three of the participants each used three strategies interchangeably with high frequency (see Table 2 below). 
Table 2. Participants' dominant strategy and learning background compared to test score

\begin{tabular}{|c|c|c|c|}
\hline Participant & Score (out of 64) & Dominant Strategy & Learning Background \\
\hline 1 & 43 & $\mathrm{P}$ & 2 years private study \\
\hline 2 & 39 & NR & $\begin{array}{l}3 \text { years primary, } 5 \text { years } \\
\text { high school }\end{array}$ \\
\hline 3 & 49 & NR, P, EP & $\begin{array}{l}3 \text { years primary, } 5 \text { years } \\
\text { high school }\end{array}$ \\
\hline 4 & 53 & P, ES & 6 years high school \\
\hline 5 & 39 & NR, IR & $\begin{array}{l}2 \text { years primary, } 5 \text { years } \\
\text { high school }\end{array}$ \\
\hline 6 & 53 & IR, P & $\begin{array}{l}3 \text { years high school, } 16 \text { months } \\
\text { in Japan }\end{array}$ \\
\hline 7 & 47 & EP & 4 years high school \\
\hline 8 & 44 & NR, P & 5 years high school \\
\hline 9 & 52 & IR, ES & 5 years high school \\
\hline 10 & 40 & NR, IR & 5 years high school \\
\hline 11 & 49 & IR, P & $\begin{array}{l}3 \text { years primary, } 5 \text { years } \\
\text { high school }\end{array}$ \\
\hline 12 & 43 & IR, P, EP & 4 years high school \\
\hline 13 & 38 & IR & $\begin{array}{l}2 \text { years in Macau, } 2 \text { weeks } \\
\text { in Japan }\end{array}$ \\
\hline 14 & 53 & IR, P & 5 years high school \\
\hline 15 & 54 & IR & 4 years high school \\
\hline 16 & 40 & IR, EP & 5 years high school \\
\hline 17 & 48 & IR, P & 4 years high school \\
\hline 18 & 37 & IR, P & None \\
\hline 19 & 37 & IR & 2 years high school \\
\hline 20 & 36 & IR, NR & None \\
\hline 21 & 44 & IR, P & None \\
\hline
\end{tabular}


Previous researchers ${ }^{39}$ have made anecdotal assumptions that JFL learners transliterate loanwords only either according to their own pronunciation or according to the English spelling of the word. These are, using the terminology of this study, the English Pronunciation (EP) and the English Spelling (ES) strategies. However, the results of this study indicate that learners do not rely solely on these two strategies and in fact use at least three other strategies in addition to these.

It was revealed that fifteen out of the twenty-one learners interviewed used the Inductive Rules (IR) strategy as their predominant or one of their predominant strategies for transliterating foreign loanwords. The second most dominant strategy, adopted by twelve participants, was the Precedent $(\mathrm{P})$ strategy, followed by the No Rules (NR) strategy, which was the predominant strategy of six of the twenty-one informants. In contrast only four of the twenty-one participants were identified as using the EP strategy predominantly and only two of the participants used the ES strategy predominantly. Furthermore, the ES strategy was not the single predominant strategy of any participant. This indicates that the ES and EP strategies are not used by JFL learners as commonly as previously assumed and moreover, that they are rarely relied upon as a learner's sole guide for transliteration of loanwords.

\section{Evaluation of success of strategies}

The results of the data analysis showed that predominant use of the $\mathrm{P}$ strategy produced a high rate of accurate transliteration. Participants who used P strategy as a supplementary strategy also produced higher rates of accurate transliteration. It was also found that participants who predominantly relied on only one strategy produced a relatively low rate of accuracy.

The highest-scoring participant, number 15, who scored 54 points, was characterised as using the $\mathrm{P}$ strategy second-most frequently to his predominant strategy, which was the IR strategy. This implies that his IR system may be based on rules inferred from correctly transliterated precedents and therefore is able to produce a high rate of accurate transliterations. In contrast, Participant 20, who scored the lowest, at 36 out of 64 points, used the IR strategy the most frequently out of the four strategies she was identified as using, while the next strategy used more frequently was the NR strategy. The learner's unsuccessful use of IR strategy indicates that the inducted rules are mistaken or underdeveloped at this stage.

39 Ohso, op. cit.; Kawarazaki, op. cit.; Kawarazaki, 'Katakana no shidō: Gairaigo no hyōki no shikata', pp. 35 - 49; Takebe, 'Nihongo kyōiku ni okeru katakana no mondai,' pp. 1 - 17; Inagaki, op. cit. 
The P strategy was also found to be the predominant strategy of the four other participants who achieved scores higher than fifty points. One of the three participants who gained a score of 53 points used P strategy in conjunction with English Spelling (ES), while the other two used Inducted Rules (IR) most frequently after P strategy. The participant who scored 52 points had only nine justifications, five of which were indicative of IR strategy, three of ES strategy, while only one justification was classed as No Rule (NR). From these results it can be seen that P strategy as a dominant transliteration strategy tends to produce a high rate of accuracy of transliteration.

Participants who were identified as predominantly using only one strategy also achieved a range of scores. Participants 1, 2, 7, 13 and 19, who used supplementary strategies in very low proportions, produced low rates of accuracy in comparison to Participant 15 who, as mentioned earlier, used a secondary strategy with relatively high frequency. All strategies with the exception of ES were identified at least once as the only predominant strategy used by a participant. In other words, the IR strategy was the dominant strategy employed by Participants 13, 15 and 19, who scored 38, 54 and 37 respectively. These scores encompass the highest score (54) and two of the lowest scores out of all twenty-one participants. As discussed above, Participant 15 also employed the $\mathrm{P}$ strategy as a secondary strategy, implying that a relatively reliable basis for his internalised system of rules exists. By contrast, Participants 13 and 19 reported only minor use of other strategies. Participant 13 gave ten justifications, only two of which indicated P strategy, and one which was NR. Participant 19 gave fifteen justifications of which one was classified as ES, one as NR and two as P. This implies that learners who use IR as a single predominant strategy produce a lower rate of accuracy in transliteration. Single predominant use of P and NR strategies by Participants 1 and 2 respectively, both produced comparatively low scores, with Participant 1 scoring 43 and Participant 2 scoring 39 points out of 64. These results indicate that even a more successful strategy such as $\mathrm{P}$, if not supplemented by another strategy, will produce a lower rate of accuracy comparable to that of a less successful strategy such as NR. In contrast, Participant 7's predominant use of the EP strategy achieved a relatively high score of 47 which implies that when taken as a lone strategy, this strategy produces higher rates of accurate transliteration than P and NR. Overall, the figures discussed here demonstrate that participants who predominantly relied on one strategy produced a relatively low rate of accuracy in transliterating.

\section{Success of strategy pairs}

The findings of this study indicate that learners tend to use two or more strategies when transliterating loanwords into katakana. Learners who used the IR and P strategy pair 
tended to be more successful in producing accurate transliterations. The strategy pair NR and IR tended to produce the lowest rates of accuracy.

In this study the majority of the participants (fifteen out of twenty-one) used at least two or more of the five strategies. Three strategies were used by Participant 3 , who used the NR, P and EP strategies with almost equal frequency, gaining a score of 49 out of 64 points, and Participant 12, who used IR, P and ES strategies frequently, which resulted in a score of 43 points. These two examples do not indicate that using numerous strategies with equal frequency improves accuracy of transliteration. However, on examination of which strategies were used in combination by 15 participants in the study, it is possible to hypothesise as to which strategies, when used with similarly high frequency, produce higher accuracy in transliteration.

Strategy pairs were found in the 6 following combinations: P and ES, NR and IR, IR and $P, N R$ and $P, I R$ and ES, and IR and EP. The IR and P combination was used the most frequently (by six participants) followed by the NR and IR combination, which was used by three participants. All other combinations were each used by one participant. The IR and P combination achieved relatively high scores of 53, 53, 49 and 48, from Participants 6, 14, 11 and 17 respectively. However, Participants 18 and 21, who also used this combination, produced lower scores of 37 and 44 points respectively. By comparison, the NR and IR combination used by Participants 5, 10 and 20, resulted in consistently lower scores of 39, 40 and 36 points respectively. These results indicate that overall, the IR and $\mathrm{P}$ combination was more successful at producing accurate transliteration than the NR and IR combination.

High scores were also achieved by Participants 4 and 9, who were found to predominantly use ES strategy in conjunction with another strategy. Participant 4 employed the $\mathrm{P}$ and ES combination which achieved a score of 53 out of 64 points, while Participant 9 predominantly used IR and ES in combination which resulted in a score of 52 points. Comparatively low scores were gained from the two participants who used the combinations NR and P, and IR and EP. Participant 8, who used the former combination scored 44, and Participant 16 used the latter, scoring 40 out of 64 points.

\section{Extra-Curricular Exposure to Japanese Language}

A comparison of the participants' test scores with their extra-curricular exposure to Japanese language supports the hypothesis that extensive aural exposure to Japanese language increases the tendency to produce accurate transliterations. The type of exposure also seems to influence strategy formation, and offers an explanation for the differences in score between participants who both used the IR strategy. 
The majority of the participants reported at least one source of significant exposure to Japanese language from sources outside the classroom. Only participants 19 and 20 had experienced no extra-curricular exposure to Japanese. Participants received exposure from a variety of sources as shown in the table below, ranging from Japanese movies to Japanese conversation clubs at university.

Table 3. Participants' Test Score vs. Predominantly Used Strategy vs. Type of ExtraCurricular Exposure to Japanese Language

\begin{tabular}{|c|c|c|c|}
\hline Participant & $\begin{array}{l}\text { Score } \\
\text { (out of 64) }\end{array}$ & Strategy & Type of Exposure \\
\hline 1 & 43 & $\mathrm{P}$ & $\begin{array}{l}\text { Japanese TV dramas, anime, Japanese pop music, } \\
\text { basic books }\end{array}$ \\
\hline 2 & 39 & NR & Homestay students \\
\hline 3 & 49 & NR, P, EP & Manga, anime, 8 days in Japan \\
\hline 4 & 53 & P, ES & $\begin{array}{l}\text { Conversation club, Japanese friends, } 2 \text { week } \\
\text { exchange, internet blogs, TV dramas, movies }\end{array}$ \\
\hline 5 & 39 & NR, IR & $\begin{array}{l}1 \text { week holiday, } 3 \text { week exchange, anime, penpal, } \\
\text { Japanese friends, conversation class }\end{array}$ \\
\hline 6 & 53 & IR, P & 16 months in Japan, Japanese friends \\
\hline 7 & 47 & EP & Movies, Japanese pop music, conversation class \\
\hline 8 & 44 & NR, P & 2 week trip to Japan, homestay students \\
\hline 9 & 52 & IR, ES & $\begin{array}{l}\text { TV dramas, books, manga, friends, regular } \\
\text { holidays in Japan }\end{array}$ \\
\hline 10 & 40 & NR, IR & 6 week exchange trip, manga, e-pal \\
\hline 11 & 49 & IR, P & $\begin{array}{l}\text { Anime, music, homestay student, } 2 \text { weeks in } \\
\text { Japan, friends who study Japanese }\end{array}$ \\
\hline 12 & 43 & IR, P, EP & $\begin{array}{l}\text { TV dramas, Japanese friends, Japanese } \\
\text { conversation class }\end{array}$ \\
\hline 13 & 38 & IR & Manga, TV dramas, 2 weeks of study in Japan \\
\hline 14 & 53 & IR, $\mathrm{P}$ & Japanese movies \\
\hline 15 & 54 & IR & TV dramas, anime, games \\
\hline 16 & 40 & IR, EP & 2 week holiday to Japan \\
\hline
\end{tabular}




\begin{tabular}{|l|l|l|l|}
\hline 17 & 48 & IR, P & $\begin{array}{l}\text { TV dramas, anime, Japanese club, 2 short trips } \\
\text { to Japan }\end{array}$ \\
\hline 18 & 37 & IR, P & Movies, Japanese game shows \\
\hline 19 & 37 & IR & None/Japanese movies \\
\hline 20 & 36 & IR, NR & None \\
\hline 21 & 44 & IR, P & Anime \\
\hline
\end{tabular}

There is evidence in the data to propose a hypothesis that the different types of exposure a learner receives encourages the formation of different strategies and thus improves the accuracy of transliteration to varying degrees. Evidence to support this can be found by examining the extra-curricular exposures of the 5 highest-scoring participants. Except for Participant 14, who reported only minor exposure to Japanese movies, the other four participants received significant exposure from aural sources and some from visual sources. Participant 4, with a score of 53, listed exposure from Japanese TV and movies, internet blogs, friendships with native Japanese speakers, conversation club and a 2 week educational trip to Japan. This participant received exposure from numerous sources, mainly in aural form, supplemented by visual exposure in the form of internet blogs. Participant 6 also identified friendships with native Japanese speakers as a significant source of exposure, in addition to the 16 months she had spent in Japan. Similar sources of exposure were reported by Participant 9, who added books and manga to his list which comprised Japanese TV, native Japanese friends and regular holidays in Japan. Significant aural exposure from TV, interaction with native speakers and regular in-country experience in combination with visual exposure from books and manga produced a high score of 52 for this participant. The highest scorer, Participant 15, again reported Japanese TV and anime as a significant source of exposure, in addition to Japanese computer games. All of these sources can be classified as predominantly aural types of exposure. However, some visual exposure was gained from the computer games, as evidenced by the fact that during his interview, he stated that he had originally learned katakana symbols from their appearance in these games. From these limited examples, it can be hypothesised that significant aural exposure to Japanese, in conjunction with an extensive learning background (these high scorers had previously studied JFL for at least 3 years in high school), are optimal characteristics for producing a higher rate of transliteration accuracy.

Visual exposure to loanwords could be gained particularly from sources such as books (including manga), internet blogs, computer games and letters from pen pals, while aural exposure could be received from TV programs, movies, music and Japanese native speakers. These two types of exposure could be very useful for internalising 
accurately transliterated forms. Visual exposure shows the transliteration of words or similar words that the learners can remember and copy, or from which they can extrapolate rules. Aural exposure provides examples of the japanisation of sounds. (This is arguably the most crucial skill.) In the same way, aural exposure creates a body of examples from which learners can extrapolate rules to copy examples.

A comparison of Participants 20 and 21 provides evidence to support the idea of a positive correlation between the amount of extra-curricular exposure to Japanese and accuracy of transliteration. Both these participants lacked any prior learning experience of Japanese. However, Participant 21 used the combinations of strategies IR and $\mathrm{P}$ and, with a score of 44, scored significantly higher than Participant 20, who received the lowest score - 36 points, using combination IR and NR. Due to the fact that their learning backgrounds are identical, the difference in score and strategy use between these two participants could be explained by the difference between their extra-curricular exposures to Japanese. In contrast to Participant 20, who reported no extra-curricular exposure to Japanese, Participant 21 identified anime as a significant source of exposure to Japanese. According to Ellis, Basturkmen and Loewen ${ }^{40}$ implicit learning (without receiving explicit instruction) requires exposure to a large sample. The more complicated the rules of the system to be learned, the larger the sample size that is required for the formulation of reliable generalisations. Thus it can be said that Participant 21, due to his exposure to Japanese language through anime has been able to form more reliable generalisations with regards to transliteration rules. This comparison of Participants 20 and 21 provides evidence to suggest that some informal exposure results in more effective strategies and higher accuracy of transliteration.

Participants 2 and 5 also provide a useful comparison which indicates that different types of strategies may be formed as a result of different types of extracurricular exposure. These two participants each had in common an extensive learning experience of JFL, with Participant 2 recording 3 years of primary and 5 years of high school study, and Participant 5 recording 2 years of primary and 5 years of study at high school. They scored identically low scores of 39 out of 64 . However, Participant 2 used solely NR as a predominant strategy, while Participant 5 used a combination of IR and NR. Participant 2's only extra-curricular exposure to Japanese came in the form of native Japanese home stay students, Participant 5 listed anime, Japanese pen pal, Japanese friends, conversation club and four weeks in total spent in Japan, three of which were for study purposes. Participant 2 may have received aural exposure through home stay students, but Participant 5 has clearly gained more aural exposure through anime, Japanese friends, conversation club and visual exposure through a pen pal. She would

40 Ellis, Basturkmen and Loewen, 'Preemptive Focus on Form in the ESL Classroom,' pp. 407 - 432. 
have also received both types of exposure from her in-country experience. Although this extensive extra-curricular exposure to Japanese language did not increase Participant 5's accuracy in transliteration, it may account for her use of IR in conjunction with NR as a predominant transliteration strategy. That is, her large amount of exposure to Japanese may have provided her with enough linguistic input to internalise rules by which to transliterate, although the reliability of these rules is doubtful, judging by her low score. Participant 5's use of IR, while currently unsuccessful, could signify an intermediate stage of development, positioned between NR and successful use of IR. By contrast, Participant 2 shows that little outside exposure to Japanese can produce use of a less successful strategy due to lack of linguistic input with which to formulate internal rules.

An exploration of the interaction between extra-curricular exposure and accuracy of transliteration revealed that overall, more exposure led to higher accuracy in transliteration. In terms of extra-curricular exposure to Japanese language study, there was a tendency for participants with a high score of accuracy to have had significant aural exposure to Japanese. Further, a comparison of the scores of Participants 20 and 21, both of whom had had no prior learning background in Japanese, indicate that Participant 21's extra-curricular exposure to Japanese resulted in the use of more successful strategies, which produced higher accuracy. A comparison of Participants 2 and 5 also provided evidence to show that a greater amount of exposure can result in the use of more successful strategy types, although in this case Participant 5's score of accuracy was not increased by her use of IR in conjunction with NR.

\section{Conclusion}

Previous research conducted in the area of learners' transliteration of loanwords into katakana symbols has been concentrated on error analysis and founded on the premise that learners transliterate loanwords based on a) the original pronunciation of a word or b) the original spelling of the word. This has provided no evidence of JFL learners' knowledge of rules or guidelines that have been established for transliteration. In fact, Inagaki's study ${ }^{41}$ was based on the assumption that learners were unaware of rules. The study conducted here was consistent with prior research in showing that students were unaware of official guidelines for transliteration. However, more importantly, all but two of the participants showed awareness of the notion of rules for transliterating loanwords.

This study identified and described 5 types of strategies that learners use when transliterating, as follows:

41 Inagaki, op. cit. 
- Precedent $(\mathrm{P})$

- Inductive Rules (IR)

- English Spelling (ES)

- English Pronunciation (EP)

- No Rules (NR)

Comparisons of participants' use of pairs of these strategies with their accuracy in transliterating loanwords into katakana symbols revealed that the strategy pairs of $\mathrm{P}$ and ES, IR and P, and IR and ES produced the highest accuracy scores on the transliteration test. That is, participants who were more successful in producing accurate transliterations were guided by:

a) the spelling of the English form of the word

b) previous exposure to the correct transliteration in some form

c) internalised rules informed by a) and b)

It was found that participants who used NR, which is effectively 'no strategy', produced transliterations of lower accuracy, even when supplemented with a second strategy. This indicates that using some conscious strategy produces better accuracy, rather than transliterating arbitrarily.

Furthermore, an analysis of contributing factors such as learner history and extra-curricular exposure, compared with participants' test scores, showed that students who had received extensive aural exposure to the Japanese language tended to use $\mathrm{P}$ and IR strategies, and had a relatively higher rate of transliterating accurately. This data provided evidence to support the hypothesis that greater aural exposure to the Japanese language gives learners a more reliable system of internalised rules for transliteration.

While small scale in nature, this research has revealed many questions that could be addressed in further research aimed at understanding how JFL learners learn and use loanwords of English origin. Clearly, confirmation of these results with more learners over a wider range of proficiency levels is needed. Investigating the differences between beginners' strategies and advanced learners' strategies could determine whether there is a developmental sequence in strategy use. Possible future studies could also compare native Japanese speakers' use of transliteration strategies with that of JFL learners.

The question of the usefulness of strategy training for learners also bears closer investigation. Certain learners in this study used IR successfully without such training, showing it to be a natural process. However, this was not the case for all the participants, 
and pedagogical intervention may have benefits for those types of learners. Additionally, the findings of this study suggest that strategy use is highly differential. Therefore a study of the impact of learners' Individual Differences on strategy development would also be valuable.

There are also pedagogical questions that need to be answered. There are indications that explicit instruction on established transliteration rules could improve learners' accuracy. The nature and timing of that instruction is a matter for further investigation. Such investigation should take into consideration the strategies identified in this research and develop a pedagogy that develops the use of them. Explicit instruction on loanwords could develop greater accuracy of transliteration, while raising awareness in learners of the existence of established transliteration rules.

\section{References}

Backhouse, A. E., The Japanese Language: An Introduction (Melbourne: Oxford University Press, 1993).

Brown, R., Pressley, M., Van Meter, P. and Schuder, T., 'A Quasi-experimental Validation of Transactional Strategy Instruction with Low-achieving Second-grade Students,' Journal of Educational Psychology, vol. 88, (June 1996), pp. $18-37$.

Chamot, A. and Küpper, L., 'Learning strategies in foreign language instruction', Foreign Language Annals, vol. 22, (1989), pp. $13-24$.

Cohen, A., 'On taking language tests: what the students report', Language Testing, vol. 1, (1984), pp. 70 - 81.

Cohen, A. and Robbins, N., 'Toward assessing interlanguage performance: The relationship between selected errors, learners' characteristics and learners' explanations', Language Learning, vol. 26, (1976), pp. 45 - 66.

DeKeyser, R., 'Implicit and explicit learning', in Doughty, C. and Long, M. H. (eds.), The handbook of second language acquisition (London: Blackwell, 2003), pp. 313 - 348.

Ellis, R., Basturkmen, H. et al., 'Preemptive Focus on Form in the ESL Classroom', TESOL Quarterly, vol. 35, no. 3 (2001), pp. $407-432$.

Ericsson, K. and Simon, H., 'Verbal reports on thinking', in Faerch, C. and Kasper, G. (eds.), Introspection in Second Language Research (Clevedon, Avon: Multilingual Matters, 1987), pp. 24 - 54.

'Gairaigo ni kansuru ishiki chōsa' [The survey on loanwords], The National Institute for Japanese Language (Kokuritsu Kokugo Kenkyūjo, NIJL). Retrieved 23 March 2007, from http://www.kokken.go.jp/katsudo/kenkyu_jyo/genzai/ishiki/4-6.html.

'Gairaigo no hyōki' [Transcription of Loanwords], The Agency for Cultural Affairs (Bunka-chō, ACA). Retrieved 23 March 2007, from http://www.bunka.go.jp/kokugo/frame.asp?tm=20050214142612.

Gass, S., Input, interaction, and the Second Language Learner (Mahwah, NJ: Lawrence Erlbaum Associates, 1997). 
Gass, S. and Selinker, L., Second Language Acquisition: An Introductory Course (New Jersey: Lawrence Erlbaum Associates, Inc., 1994).

Geminate. (n.d.). The American Heritage Dictionary of the English Language, Fourth Edition. Retrieved 15 October 2007, from http://dictionary.reference.com/browse/geminate.

Hadley, A. (ed.), Research in Language Learning: Principles, Processes and Prospects (Lincolnwood, IL: Nation Textbook Company, 1993).

Hatch, E. and Yoshitomi, A., 'Cognitive Processes in language learning', in Hadley, A. (ed.), Research in Language Learning: Principles, Processes and Prospects (Lincolnwood, IL: National Textbook Company, 1993), pp. 66 - 95.

Hosenfeld, C., 'Learning about learning: Discovering our students' strategies', Foreign Language Annals, vol. 9, (1976), pp. $117-129$.

Igarashi, Y., 'The Changing Role of Katakana in the Japanese Writing System: Processing and Pedagogical Dimensions for Native Speakers and Foreign Learners', University of Victoria Dspace. Retrieved 12 August 2007, from http://dspace.library.uvic.ca:8080/bitstream/1828/189/1/PhD\%20dissertation.pdf.

Inagaki, S., 'Gairaigo Hyōki no kijun to kan'yō' [Standardization and Customary Usage in the Writing System of Loanwords], Nihongo Kyōiku, vol. 74, (1991), pp. 60 - 73.

Kawarazaki, M., 'Katakana no shidō: Gairaigo no hyōki no shikata' [Teaching katakana: How to transcribe foreign loanwords], Nihongo Kyōiku, vol. 36, (1978), pp. 35 - 49.

Kawarazaki, M., 'Katakana no dōnyū ni tsuite' [Introduction of katakana], Nihongo Kyōiku, vol. 42, (1980), pp. 17 - 28.

Kobayashi, M., Quackenbush, H. and Fukada, A., 'Gairaigo ni mirareru nihongoka kisoku no shūtoku' [Acquisition of Japanization rules in loanwords], Nihongo Kyōiku, vol. 74, (1991), pp. 48 - 60.

Leow, R. and Morgan-Short, K., 'To think aloud or not to think aloud: The issue of reactivity in SLA research methodology' [Electronic version], Studies in Second Language Acquisition, vol. 26, (2004), pp. 35 - 57.

Neustupný, J. V., Communicating with the Japanese (Tokyo: The Japan Times, Ltd., 1987).

Ohso, M., 'Eiongo no onkata no nihongoka' [Phonological forms of English loanwords in Japanese], Nihongo Kyōiku, vol. 74, (1991), pp. $34-48$.

O'Malley, J. M. and Chamot, A., Learning strategies in Second Language Acquisition (Melbourne: Cambridge University Press, 1990).

O'Malley, J. M., Chamot, A. and Küpper, L., 'Listening comprehension strategies in second language acquisition', Applied Linguistics, vol. 10, no. 4, (1989), pp. 418 - 437.

Oshima, K., Gairaigo usage in Japan: From Cultural Controversy to a New Analytical Framework (UMI Dissertation Services, 2002).

Oxford, R. L. and Crookall, D., 'Research on Language Learning Strategies: Methods, findings, and instructional issues', The Modern Language Journal, vol. 73, no. 4 (1989), pp. 404 - 419.

Preston, D. and Yamagata, A., 'Katakana representation of English loanwords: Moraconservation and variable learner strategies' [Electronic version], Journal of Sociolinguistics, vol. 8, no. 3 (2004), pp. 359 - 379. 
New Voices Volume 4

Quackenbush, H., 'English Loanwords in Japanese: Why are they difficult for English-speaking students?' [Electronic version], The Journal of the Association of Teachers of Japanese, vol. 12, no. 2 (1977), pp. 149 - 173.

Sakai, N. and Nishihira, K., Learning katakana words from the news - 350 Words (Tokyo: ALC Publishing, 1999).

Takebe, Y., 'Nihongo kyōiku ni okeru katakana no mondai' [Problems involving loanwords in the teaching of Japanese], Nihongo Kyōiku, vol. 42, (1980), pp. 1 - 17. 